\title{
PREDICTABILITY OF FORMATION DAMAGE \\ AN ASSESSMENT STUDY AND GENERALIZED MODELS
}

\author{
Quarterly Report for the Period \\ April-June 1991 \\ By \\ Faruk Civan

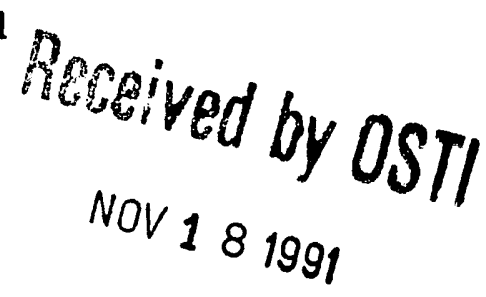

Work Performed Under Contract No. AC22-90BC14658

\author{
Gene Pauling, Project Manager \\ Metarie Site office \\ 900 Commerce Road, East \\ New Orleans, I.A 70123
}

\author{
$f^{2}$ \\ University of Oklahoma \\ Norman, OK
}

DISTRIBUTION OF THIS DOCUMENT IS IENLIMITEO

\section{DISCLAIMER}

\footnotetext{
This report was prepared as an account of work sponsored by an agency of the United States Government. Neither the United States Government nor any agency thereof, wor any of their employees, makes any warranty, express or implied, or assumes any legal liability or responsibility for the accuracy, completeness, or usefulness of any information, apparatus, product, or process disclosed, or represents that its use would not infringe privately owned rights. Reference herein to any specific commercial product, process, or service by trade name, trademark, manufacturer, or otherwise does not necessarily constitute or imply its endorsement, recommendation, or favoring by the United States Government or any agency thereof. The views and opinions of authors expressed herein do not necessarily state or reflect those of the United States Government or any agency thereof.
} 


\section{QUARTERLY REPORT}

\author{
April - June 1991 Period
}

CONTRACT TITLE:

CONTRACT NUMBER:

CONTRACTOR ORGANIZATION: University of Oklahoma

PRINCIPAL INVESTIGATOR: Faruk Civan
Predictability of Formation Damage - An

Assessment Study and Generalized Models

DE-AC22-90BC14658

\section{OBJECTIVES:}

The project objective is to develop improved generalized predictive models to be used for investigation of reservoir formation damage and control for various fluid and rock conditions and to account for these effects in reservoir simulation.

To accomplish its objective the proposed study will first critically study and evaluate the previous modeling efforts and the experimental studies reported in the literature. Then, generalized predictive models will be formulated by combining the previous attempts and by improving and generalizing the modeling approaches to accommodate for a wide variety of conditions encountered in actual field applications.

A critical review of the previous work addressing their theoretical basis, assumptions and limitations, and the generalized and improved model developed in this study will be presented in a systematic manner in terms of a standardized definition and nomenclature for direct comparison. Case studies with the generalized model will be presented to demonstrate its capacity and vaidity. User friendly computer programs implementing the improved modeling approaches will also be supplied.

This study will form an assessment of the presently available models and methods for evaluating and predicting formation damage and present improved models. Therefore, it will be an important reference for the petroleum industry.

\section{SUMMARY OF PROGRESS}

Presently, two graduate students are participating in the research efforts. The specific tasks and names of the students are as follows: 
1. A Study of Dissolution and Precipitation Effects on Formation Damage, F. Chang, Ph.D. Expected to be completed in May 1991.

2. Formation Damage in Two-Phase Flow Through Porous Media, L. Xinghui, Ph.D. (in progress)

\section{SIGNIFICANT ACCOMPLISHMENTS}

1. One paper has been presented:

- Chung, F. F. and Civan, F., Modeling Formation Damage by Dissolution/Precipitation Processes in Petroleum Reservoirs, presented at the 65th Colloid and Surface Science Symposium, Enhanced Oil Recovery Session, June 14-19, 1991, Norman, Oklahoma.

2. The Ohen and Civan formation damage model has been extended to include the chemical dissolution and precipitation effects. Currently, we are in the process of validating the extended model with experimental data. Simultaneously, to generate our own core data, we are preparing for laboratory tests under controlled conditions.

3. The preparation and documentation of the state-of-the-art modeling approaches on rock/fluid interactions are continuing.

\section{SIGNIFICANCE TO EOR RESEARCH PLAN}

Controlling formation damage and efficient selective plugging of heterogeneous reservoir formation are among the important issues for improving the sweep efficiency of enhanced oil recovery. For the most part, the methods proposed for controlling the formation characteristics to achieve good sweep efficiency have not been satisfactory. In many cases the efforts for the improvement of sweep efficiency resulted with adverse effects.

The present study critically analyzes the various processes influencing the sweep efficiency during enhanced oil recovery. The relevant studies and results reported in the literature are reviewed and incorporated into the analysis. The effect of various factors are discussed and illustrated by means of typical case studies. Finally, an overall assessment of the processes controlling the sweep efficiency is presented in a systematic manner for reference.

\section{FUTURE RESEARCH PLANS}

The overall objective is to develop a working generalized model that can be used for characterizing, evaluating, and preventing formation damage in oil and gas reservoirs. Hence this model will be a useful tool for development of strategies to maximize the performance 
of oil and gas production from in-situ reservoirs. Future research efforts will be carried out towards accomplishing this objective by means of experimental and theoretical studies. 


\section{PUBLICATIONS}

1. Civan, F., Knapp, R.M. , and Ohen, H.A. "Alteration of Permeability by Fine Particle Processes," J. Petroleum Science and Engineering, Vol. 3, Nos. 1/2, pp. 65-79, October, 1989.

2. Ohen, H.A. and Civan, F. "Simulation of Formation Damage in Petroleum Reservoirs," SPE \#19420 paper, Proceedings of the 1990 SPE Symposium on Formation Damage Control, Lafayette, LA, February 22-23, 1990, pp. 185-200, also accepted for publication in SPE Journal with revision.

3. Ohen, H.A. and Civan, F. "Predicting Fines Generation, Migration and Deposition Near Injection and Production Wells," Proceedings of the First Regional Meeting, American Filtration Society, Houston, TX, October 30-November 1, 1989. pp. 161-164.

4. Ohen, H. A. and Civan, F. "Predicting Skin Effects Due to Formation Damage by Fines Migration," (partially funded by the previous DOE project), SPE 21675 paper, Proceedings of the 1991 Society of Petroleum Engineers Production Operations Symposium, April 7-9, 1991, Oklahoma City, Oklahoma, pp. 399-410.

5. Civan, F. "A Generalized Model for Formation Damage by Rock-Fluid Interactions and Particulate Processes," SPE 21183, Proceedings of SPE 1990 Latin American Petroleum Engineering Conference, October 14-19, 1990, Rio de Janeiro, Brazil.

6. Millan-Arcia, E. and Civan, F. "Characterization of Formation Damage by Particulate Processes," J. Canadian Petroleum Technology, submitted June 1990 and revised in February 1991, and accepted for publication. 

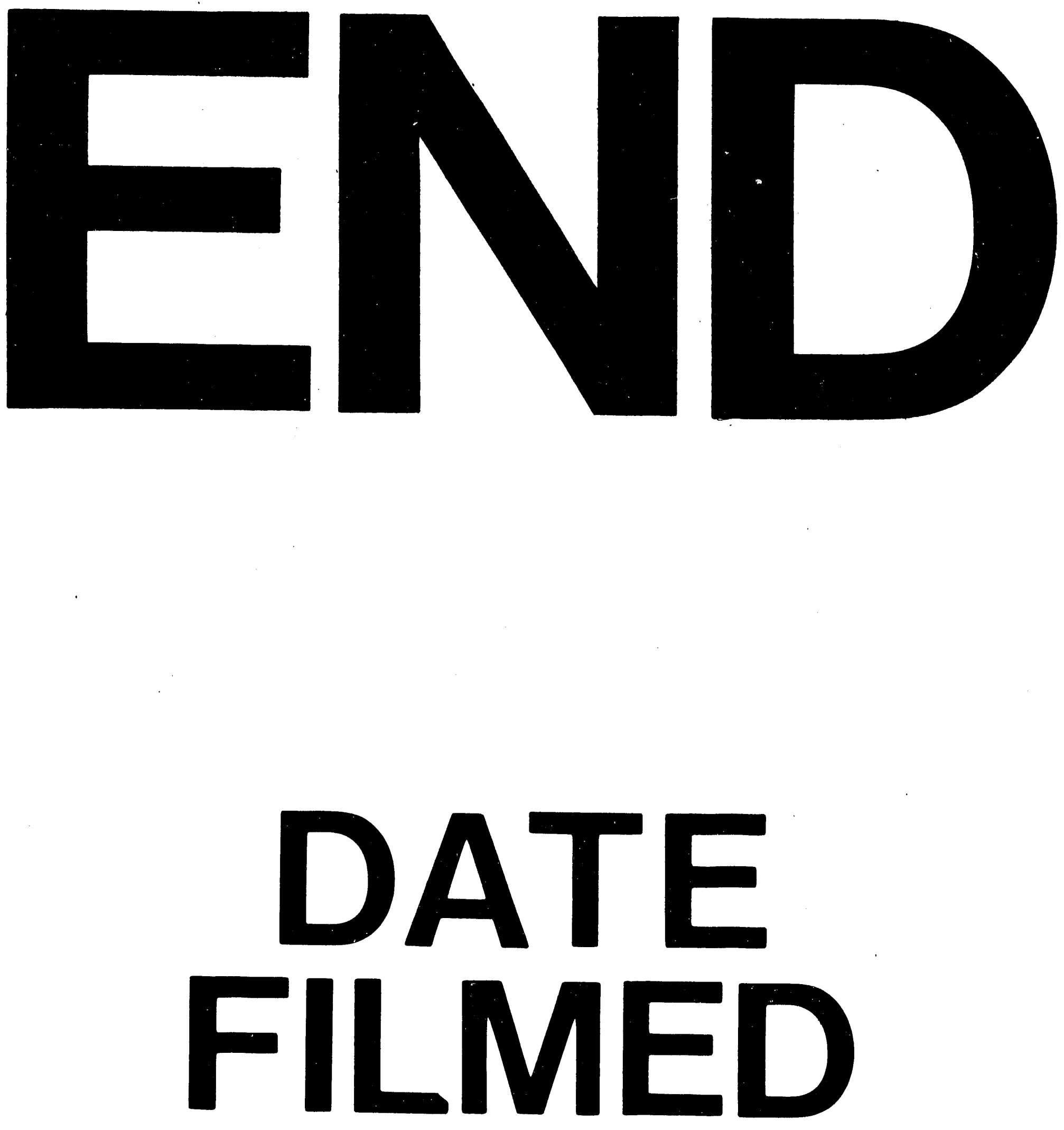

1

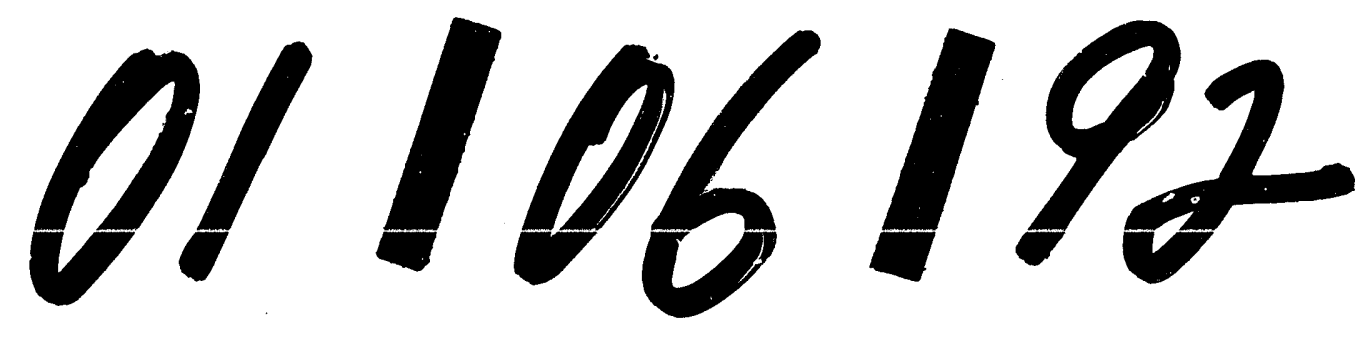


